\author{
B. Rakhadilov ${ }^{1}$, L. Zhurerova ${ }^{2}$, W. Wieleba ${ }^{3}$, Zh. Sagdoldina $^{1}$, A.K. Khassenov ${ }^{4}$ \\ ${ }^{1}$ S. Amanzholov East Kazakhstan State University, Ust-Kamenogorsk, Kazakhstan; \\ ${ }^{2}$ D. Serikbayev East-Kazakh State Technical University, Ust-Kamenogorsk, Kazakhstan; \\ ${ }^{3}$ Wroclaw University of Science and Technology, Poland \\ ${ }^{4}$ Ye.A. Buketov Karaganda State University, Kazakhstan \\ (E-mail:rakhadilovb@mail.ru)
}

\title{
Features of the structure and properties formation of AMG6 alloy under the equal channel angular pressing
}

\begin{abstract}
The results of experimental studies of changes in the structure, microhardness, and wear resistance of the AMG6 aluminum alloy during equal channel angular pressing (ECAP) are presented in this work. The evolution of the fine structure and the formation of secondary phases in the AMG6 alloy during ECAP were studied. The dark-field image of the structure of the AMg6 alloy in the matrix reflex showed the splitting of the material into small disoriented fragments of about $0.5 \mu \mathrm{m}$ in size with a small-angle disorientation boundary (about $2-5^{\circ}$ ). Optimal method and modes of ECAP of the AMG6 aluminum alloy were selected of the bases of experimental research, which make it possible to obtain a workpiece with enhanced tribological and mechanical characteristics. It was established that the most intensive grinding of the grain structure in the AMG6 alloy occurs at ECAP-12 at a channel angle intersection of $120^{\circ}$. It is shown that with a decrease in grain size, the microhardness of the alloy AMG6 after ECAP increases by 4 times, compared with the initial state. The results of the test samples for abrasive wear showed a decrease in mass loss after 12 passes of ECAP, which indicates an increase in the wear resistance of the alloy AMG6 by $13-14 \%$, compared with the initial state.
\end{abstract}

Keywords: equal channel angular pressing, the aluminum alloy, dislocation structure, micro hardness, wear resistance.

\section{Introduction}

Improving the strength which will reduce the mass of products from structural materials, is an urgent task from the point of view of the promising use of aluminum alloys [1,2]. In addition, insufficient strength significantly narrows their scope in products operating under high mechanical loads, for example: overhead power lines, cables and tires [3]. In this regard, the search for ways to increase the complex of physicomechanical properties of aluminum alloys is an important scientific problem. One of the promising approaches that improve the properties of aluminum alloys is the grinding of their grain structure to ultrafinegrained (UFG) state, by such promising methods of intensive plastic deformation (IPD) as IPD torsion (IPDT), equal channel angular pressing (ECAP), also its modification - ECAP in parallel channels (ECAPPC) [4-7]. The ECAP method has several advantages over other IPD methods, which are associated with the implementation of a simple shear scheme in the process of plastic deformation [8]. Theoretically, such a scheme makes it possible to accumulate large and uniform deformations during a processing cycle with minimal energy consumption, without changing the cross section of the workpieces. In connection with the foregoing, the aim of this work is to study the influence of the modes of equal channel angular pressing on the structure of AMG6 alloy.

\section{Materials and methods of research}

In accordance with the tasks, the aluminum alloy AMG6 widely used in modern aviation, rocket science, shipbuilding and construction was chosen as the object of study. Table 1 presents the chemical composition of the aluminum alloy of AMG6.

Ta b l e 1

The chemical composition of AMG6 alloy (GOST 4784-97)

\begin{tabular}{|c|c|c|c|c|c|c|c|c|c|}
\hline Model & $\mathrm{Fe}$ & $\mathrm{Si}$ & $\mathrm{Mn}$ & $\mathrm{Ti}$ & $\mathrm{Al}$ & $\mathrm{Cu}$ & $\mathrm{Be}$ & $\mathrm{Mg}$ & $\mathrm{Zn}$ \\
\hline AMG6 & till 0.4 & till 0.4 & $0.5-0.8$ & $0.02-0.1$ & $91.1-93.68$ & till 0.1 & $0.0002-0.005$ & $5.8-6.8$ & till 0.2 \\
\hline
\end{tabular}


Equal channel angular pressing (ECAP) is currently the most widely used IPD method. The method consists in forcing (extruding) the material through inclined channels with the same cross-sectional area (Fig. 1).
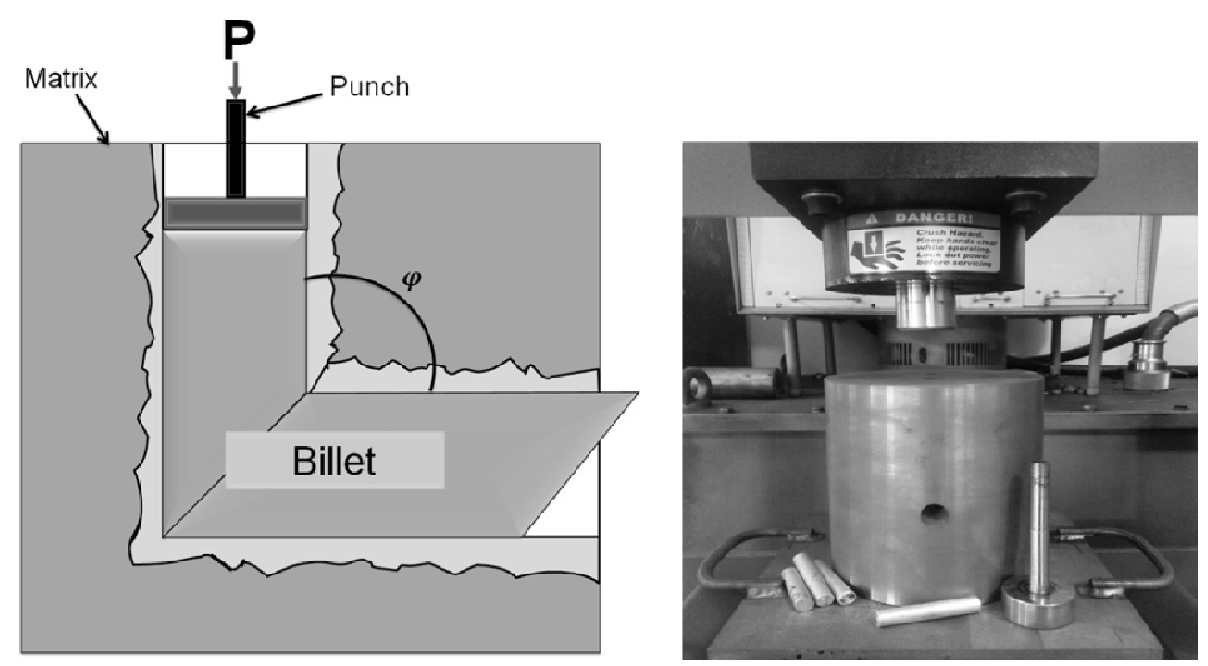

Figure 1. Scheme of the ECA pressing and press equipment with a hydraulic press for intense plastic deformation

The procedure is often repeated several times [9]. Samples provision of aluminum alloy for pressure treatment were made in the form of rods with a diameter of $12 \mathrm{~mm}$ and a length of $50 \mathrm{~mm}$. Intensive plastic deformation was carried out by the ECAP method, on a press tool (Fig. 1) [10]. The pressure source was a hydraulic press KNWP $30 \mathrm{M}$, giving a maximum pressure of up to $40 \mathrm{MPa}$. The samples were pressed with a pressure of up to $30 \mathrm{~kg} / \mathrm{cm}^{2}$, with a pressing time of up to $20 \mathrm{~s}$ per pass. The angle of intersection of the pressing channels $(F)$ was $90^{\circ}$ and $120^{\circ}$, respectively. ECAP modes are shown in Table 2.

$\mathrm{Tab} l \mathrm{e} 2$

ECAP modes of AMG6 alloy (routes B and C)

\begin{tabular}{|c|c|c|}
\hline $\begin{array}{c}\text { Aluminium } \\
\text { alloy }\end{array}$ & $F$ & $\begin{array}{c}\text { The number of cycles (passes) } \\
\text { and the accumulated deformation } N\left(e_{N}\right)\end{array}$ \\
\hline \multirow{4}{*}{ AMG6 } & 90 & $2(2.3)$ \\
\cline { 2 - 3 } & 90 & $4(4.6)$ \\
\cline { 2 - 3 } & 120 & $2(1.34)$ \\
\cline { 2 - 3 } & 120 & $4(2.68)$ \\
\cline { 2 - 3 } & 120 & $8(5.36)$ \\
\cline { 2 - 3 } & 120 & $12(8)$ \\
\hline
\end{tabular}

Optical microscopes «ALTAMI-MET-1M» and «MMP-4» (Scientific Research Institute «Nanotechnologies and New Materials» D. Serikbayev EKSTU) were used to study the general nature of the structure. The metallographic analysis method is included in a number of existing standards. The grain size was controlled by the microstructure [GOST-5639]. Quantitative metallographic analysis was performed according to the recommendations given in [10].

Structural studies were performed by thin-foil electron diffraction microscopy using a JEOL-2100 electron microscope using goniometric attachments at an accelerating voltage of $100 \mathrm{kV}$. The working magnification in the microscope column was selected from 10 to 50 times. Samples of size $10 \times 20 \times 50 \mathrm{~mm}^{3}$ were cut into plates (foils) $0.2-0.3 \mathrm{~mm}$ thick to conduct studies using spark cutting. The resulting foils were first chemically thinned in an electrolyte of $90 \%$ hydrofluoric acid and $10 \%$ perhydrol, and then electrolytically in a supersaturated solution of phosphoric acid with chromic anhydrite at room temperature, an operating voltage of $20 \mathrm{~V}$, and a current density of $4 \mathrm{~A} / \mathrm{cm}^{2}$.

The microhardness of steel samples was measured on a PMT-3M tool in accordance with GOST 945076. The microhardness of the samples was measured by the Vickers method on a PMT-3 microhardness tester with an indenter load of $\mathrm{P}=1 \mathrm{~N}$ and a holding time of $10 \mathrm{~s}$ at this load. 
Wear resistance experiments were carried out in an experimental setup for abrasive wear tests against friction to non-rigidly fixed abrasive particles according to the «rotating roller - flat surface» scheme in accordance with GOST 23.208-79, which coincides with the American standard of ASTM C 6568. The surfaces of the samples were ground and polished for abrasion testing on a rubber wheel, as well as they were cleaned with acetone and dried.

A cylindrical rubber roller pressed against the flat surface of the test sample by a radial surface with a force of $10 \mathrm{~N}$ rotated with a frequency of $1 \mathrm{~s}^{-1}$. The appearance and diagram of the device is shown in Figure 2. The rate of abrasive particles between the rubber wheel and the sample, that is, into the test area, was $41-42 \mathrm{~g} / \mathrm{min}$. As abrasive particles, electrocorundum with a granularity of $200-250 \mu \mathrm{m}$ was used. The wear resistance of the tested treated sample was evaluated by comparing its wear with the wear of a reference sample (untreated sample). Depreciation was measured by the weighing method on an ADV-200 analytical balance with an accuracy of $0.0001 \mathrm{~g}$. Samples were weighed every minute and tested for three minutes, the length of all wear was $25 \mathrm{~m}$. The samples were burned using compressed air to remove remaining sand particles on samples before weighing. The wear resistance of the test material was evaluated by the loss of mass of the samples during the test according to GOST-23.208-79.

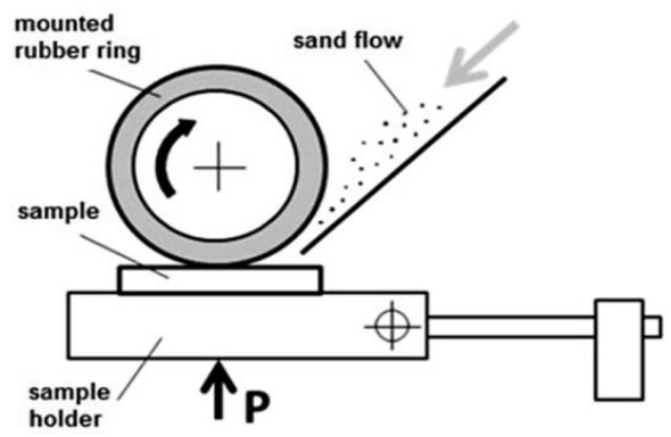

Figure 2. Tribological testing of samples

\section{Results and its discussion}

Figure 3 presents a histogram of changes in the microhardness of the AMG6 alloy depending on the ECAP mode. Increasing in microhardness is observed depending on the number of passes after ECAP. At the same time, samples treated with ECAP with an angle of intersection of channels of 900 have a higher microhardness than samples treated with ECAP with an angle of intersection of 1200. However, ECAP with an angle of intersection of 900 did not make it possible to obtain blanks with a defect-free structure with passes of more than 4. And with ECAP with a channel intersection angle of 1200, billets with a homogeneous defect-free structure were obtained with the number of passes up to 12. It was determined that as a result of ECAP (12 passes), the microhardness of the AMG6 alloy increases to $1640 \mathrm{MPa}$, which is almost 4 times higher than in the initial state.

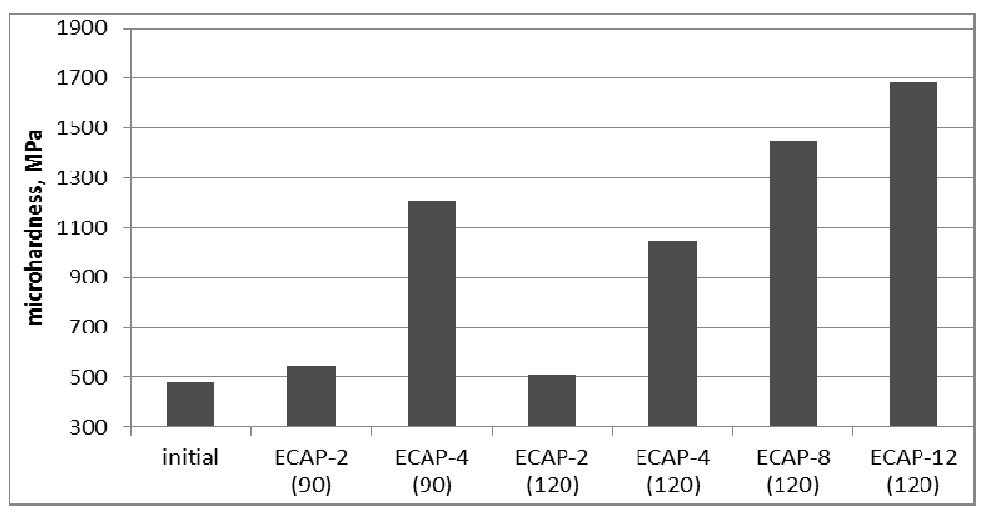

Figure 3. Microhardness of AMG6 alloy before and after ECAP 
Figure 4 presents the test results of the samples for wear resistance. It can be seen that the change in weight loss after ECAP is not significant during passages 2 and 4. Significant changes are observed only after ECAP by passage 8 and 12. Moreover, the weight loss decreases to 5.4-5.6 mg after ECAP-12, which shows an increase in wear resistance AMG6 alloy by $13-14 \%$.

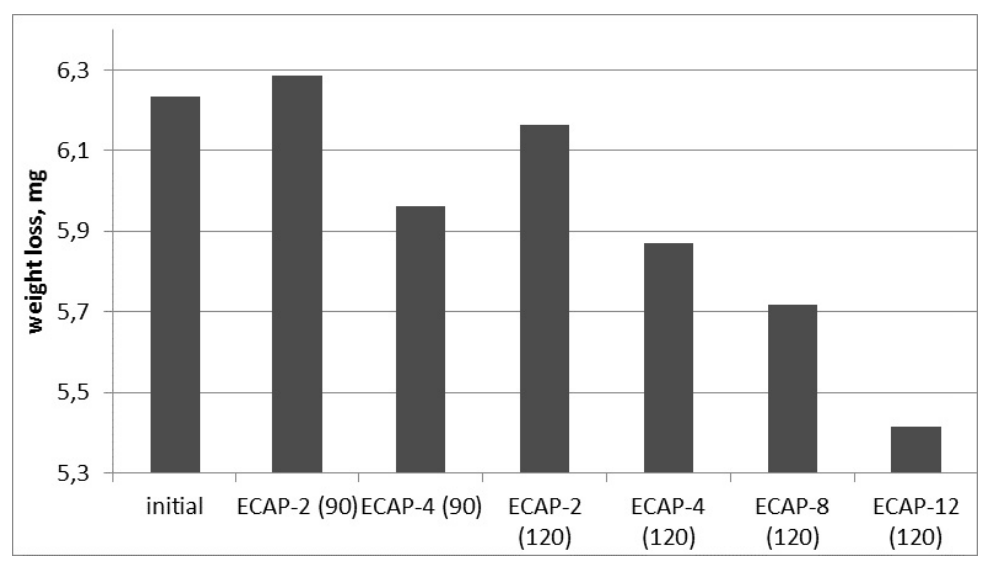

Figure 4. Wear resistance of AMG6 alloy before and after ECAP

Figure 5 shows the microstructure of the AMG6 alloy before and after ECAP. According to the results of optical microscopy, the AMG6 aluminum alloy in the initial state is characterized mainly by the equiaxed shape of the grains. It can be seen that ECAP leads to a significant refinement of the alloy structure depending on the number of ECAP passes. An analysis of the microstructure after various ECAP modes and at different channel intersection angles showed that the most intensive grain refinement in the AMG6 aluminum alloy occurs during ECAP 12 passes when the channel angle is intersected by 1200 . The grain of the starting material is crushed to sizes $\sim 1,0-1.5 \mu \mathrm{m}$ after ECAP-12. These results show that the average grain size has decreased by almost 17 times.
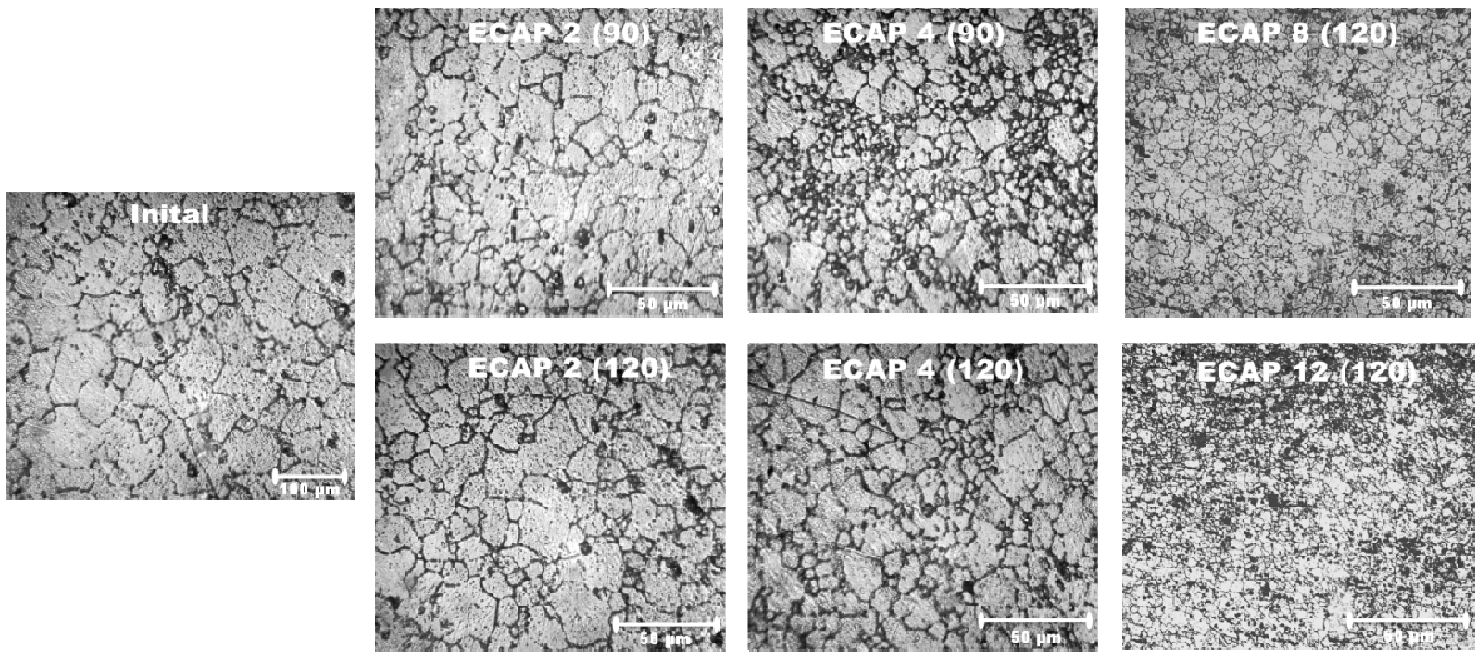

Figure 5. Microstructure of AMG6 aluminum alloy before and after ECAP

The fine structure of AMG6 alloy was also studied by REM method. Figure 6 presents bright-field images of the fine structure of the AMG6 alloy and its microdiffraction. High density of randomly distributed dislocations with a density of $2-6 \times 10^{10} \mathrm{~cm}^{-2}$ is observed in the initial state in the AMG6 alloy. Uniformly distributed particles of the second phase are observed in the volume of grains. Microdiffraction reveals reflections from the FCC phase with a lattice parameter close to the aluminum lattice parameter, as well as additional reflections from planes with interplanar spacing $d_{h k l}=2.57 \AA, d_{h k l}=2.35 \AA, d_{h k l}=2.15 \AA$, $d_{h k l}=209 \AA, d_{h k l}=1.68 \AA$. 

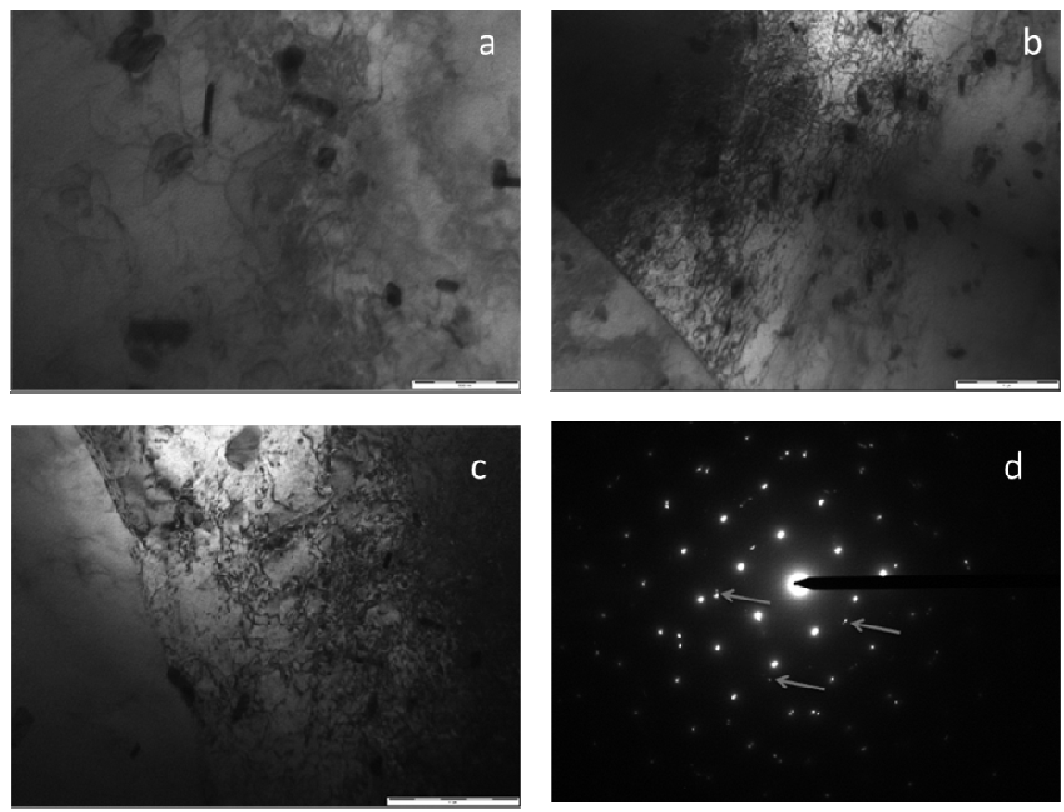

Figure 6. Bright-field images of the structure of AMG6 alloy $(a, b, c)$ and microdiffraction from the sample site $(d)$.

The (110) plane with Al parameters and individual reflections from the second phases (indicated by arrows)

The material is divided into small misoriented fragments after ECAP. Microdiffraction reveals reflections from the FCC phase with a lattice parameter close to the aluminum lattice parameter. There are separate reflections from the second phases, however, in the image of the structure of the particles of the second phases are practically not observed. The dislocation structure changes: dislocation networks are formed (indicated by arrows in Figure 7), practically no dislocations are observed inside the fragments. The size of the fragments is about $0.5 \mu \mathrm{m}$. Dark-field analysis (Figure 8) showed that most of the disorientation boundaries are small-angle (about 2-5 degrees).


Figure 7. Bright-field image of the structure of the AMG6 alloy and microdiffraction from the portion of the sample of the AMG6 alloy with Al parameters and individual reflections from the second phases (indicated by arrows) 

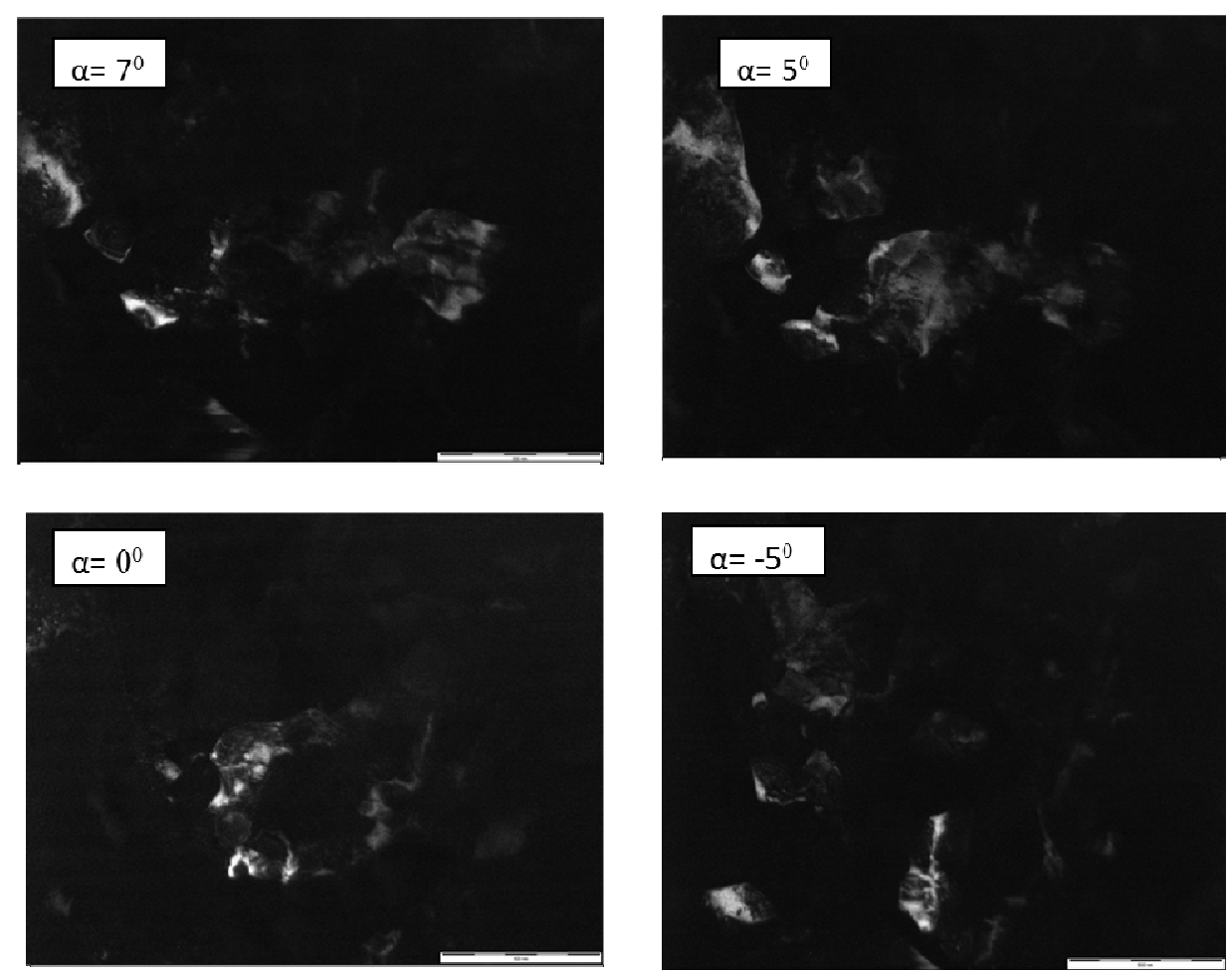

Figure 8. Dark-field image of the structure of the AMG6 alloy in the matrix reflex ( $\alpha$ - goniometer indication)

Table 3 shows the experimental data on the structure and properties of samples of AMG6 alloy obtained after ECAP under different conditions. The experimental results clearly illustrate the correlation between the structural and mechanical characteristics of alloy samples. The dependence of microhardness on the average grain size is clearly traced. Those, the microhardness of the alloy increases with a decrease in grains. This is due to the special state of the crystal lattice in grains and the structure of grain boundaries, which was discussed above.

It is seen from the generalized data presented in the Table that the refinement of the structure during ECAP is accompanied by an increase in microhardness and wear resistance in the AMG6 aluminum alloy. Different grain sizes and different tribomechanical features can be obtained by varying the number of passes.

$\mathrm{Tab} l \mathrm{e} 3$

Experimental data on the structural and mechanical features of AMG6 aluminum alloy processed by ECAP method

\begin{tabular}{|c|c|c|c|c|c|}
\hline$F$ & ECAP modes & Routes & Microhardness, MPa & $\begin{array}{c}\text { Wear resistance } \\
\text { (weight loss), mg }\end{array}$ & The average grain size $d_{\text {cp }, \mu m}$ \\
\hline- & Initial & - & 480 & 6.235 & 18.7 \\
\hline 90 & ECAP -2 & C & 545 & 6.286 & 9.14 \\
\hline 90 & ECAP -4 & B & 1210 & 5.963 & 4.17 \\
\hline 120 & ECAP -2 & C & 510 & 6.165 & 10.89 \\
\hline 120 & ECAP -4 & B & 1050 & 5.869 & 5.33 \\
\hline 120 & ECAP -8 & B & 1450 & 5.716 & 3.12 \\
\hline 120 & ECAP -12 & B & 1680 & 5.414 & 1.51 \\
\hline
\end{tabular}

\section{Conclusion}

Analyzing the experimental results obtained in the work, we can do the following conclusions:

1. Optimal method and modes of ECAP of the AMG6 aluminum alloy were selected on the bases of experimental research, which make it possible to obtain a workpiece with enhanced tribological and mechanical characteristics. 
2. It was established that the most intensive grinding of the grain structure in the AMG6 alloy occurs at ECAP-12 at a channel angle intersection of 1200 the grain of the starting material is ground to sizes of $\sim 1.0-1.5 \mu \mathrm{m}$ after ECAP-12 in the AMG6 alloy.

3. It was established that under ECAP with a channel intersection angle of $120^{\circ}$, at which the number of processing cycles reached 12 at $e=8.4$, it became possible to obtain defect-free workpieces with a more uniform structure.

4. It is shown that the microhardness of the AMG6 alloy increases with a decrease in grain size. It has been determined that the microhardness of the AMG6 alloy increases by almost 4 times as a result of equalchannel angular pressing, compared with the initial state.

5. It is shown that the weight loss decreases to 5.4-5.6 mg after ECAP-12, which shows an increase in the wear resistance of AMG6 aluminum alloy by $13-14 \%$.

6. It was determined that the dislocation structure of the AMG6 alloy changes after ECAP: dislocation networks are formed, and practically no dislocations are observed inside the fragments. The size of the fragments is about $0.5 \mu \mathrm{m}$. Dark-field analysis showed that most of the boundaries of disorientation are smallangle.

We can conclude that the developed ECAP modes can be effectively applied to a wide range of aluminum alloys. Thus, the studies showed the promise and feasibility of using ECAP to increase the hardness and wear resistance of aluminum alloys.

\section{References}

1 Елагин В.И. Конструкционные наноструктурные сплавы на алюминиевой основе / В.И. Елагин // Технология легких сплавов. - 2008. - Т. 2. - С. 6-20.

2 Rakhadilov B.K. Evolution of the structure and properties of pure aluminum under severe plastic deformation / B.K. Rakhadilov, M. Kylyshkanov, M.S. Zhaparova // IOP Conference Series: Materials Science and Engineering. — 2018. Vol. 447(1). - P. 412-417.

3 Kalombo R.B. Assessment of the fatigue failure of an All Aluminium Alloy Cable (AAAC) for a $230 \mathrm{kV}$ transmission line in the Center-West of Brazil / R.B. Kalombo, J.A. Araujo, J.L.A. Ferreira, C.R.M. da Silva, R. Alencar, A.R. Capra, R.B. Kalombo // Engineering Failure Analysis. - 2016. - Vol. 61. - P. 77-87.

4 Valiev R.Z. Bulk nanostructured materials from severe plastic deformation / R.Z. Valiev, R.K. Islamgaliev, I.V. Alexandrov // Progress in Materials Science. — 2000. - Vol. 45. - P. 103-189.

5 Gleiter H. Nanostructured Materials: Basic concept and microstructure / H. Gleiter // Acta Mater. — 2000. — Vol. 48. — P. $1-29$.

6 Утыашев Ф.З. Теория и практика деформационных методов формирования нанокристаллической структуры в металлах и сплавах / Ф.З. Утыашев, Г.И. Рааб, В.Г. Шибаков, М.М. Ганиев. - Казань: Изд-во Казан. ун-та, 2016. - 208 с.

7 Валиев Р.3. Объемные наноструктурные материалы: фундаментальные основы и применения / Р.3. Валиев, А.П. Жиляев, Т.Дж. Лэнгдон. - СПб.: Эко-Вектор, 2017. — 479 с.

8 Cerri E. An investigation of hardness and microstructure evolution of heat treatable aluminum alloys during and after equalchannel angular pressing / E. Cerri // Materials Science Forum. - 2010. - Vol. 633-634. - P. 333-340.

9 Сегал В.М. Развитие обработки материалов интенсивной сдвиговой деформацией / В.М. Сегал // Металлы. - 2004. - T. 1. - C. 5-14.

10 Rakhadilov B.K. Effect of intensive plastic deformation on microstructure and mechanical properties of aluminum alloys / B.K. Rakhadilov, A.A. Myakinin, G. Uazyrkhanova, Zh. Uazyrkhanova // IOP Conf. Series: Materials Science and Engineering. 2016. - Vol. 142. - P. 213-217.

\section{Б. Рахадилов, Л. Журерова, В. Виелеба, Ж. Сагдолдина, А.К. Хасенов}

\section{Теңканалды бұрыштық престеу кезіндегі АМГб қорытпасының құрылысы мен қасиетінің түзілу ерекшеліктері}

\footnotetext{
Жұмыста теңканалды бұрыштық престеу (ТКБП) кезіндегі АМГб алюминий қорытпасының тозуға төзімділігі мен микроқаттылығы құрылымының өзгеруін зерттеудің эксперименталды нәтижелері келтірілген. ТКБП кезіндегі АМГб қорытпасының екінші фазасының түзілуі мен жұқа қабатының эволюциясы қарастырылған. Матрицалық рефлекстегі АМГ6 қорытпасы құрылымының қараңғы бейнесі материалдың кіші бұрышында (шамамен 2-5) өлшемі 0,5 мкм жуық ұсақ фрагменттерге бөлінуін көрсетті. Эксперименталды зерттеу нәтижесінде ТКБП кезіндегі АМГб оптималды әдісі мен режимі таңдалды, осы таңдау арқылы механикалық және трибологиялық сипаттамасы жоғары болатын алюминий қорытпасы алынды. ТКБП кезіндегі АМГ6 қорытпасындағы түйіршіктік
} 
құрылымның ұсақталуы $120^{\circ}$ болғанда және каналдардың бұрышының қиылысуы кезінде болатыны анықталған. Түйіршіктер мөлшерінің азаюымен АМГ6 қорытпасының микро қаттылығы ТКБП кейін бастапқы жағдаймен салыстырғанда 4 есе артады. Абразивті тозуға үлгілерді сынау нәтижелері (ТКБП) 12 рет өткеннен кейін массаның жоғалуының төмендегенін көрсетті, бұл бастапқы жағдаймен салыстырғанда АМГб қорытпасының тозуға төзімділігінің 13-14 \% артуын көрсетті.

Кілm сөздер: теңканалды бұрыштық престеу, алюминий қорытпасы, дислокациялық құрылым, микроқаттылық, тозуға төзімділік.

\author{
Б. Рахадилов, Л. Журерова, В. Виелеба, Ж. Сагдолдина, А. Хасенов
}

\title{
Особенности формирования структуры и свойств сплава АМГб при равноканальном угловом прессовании
}

\begin{abstract}
В статье приведены результаты экспериментальных исследований изменений структуры, микротвердости и износостойкости алюминиевого сплава АМГ6 при равноканальном угловом прессовании (РКУП). Изучены эволюция тонкой структуры и формирование вторичных фаз в сплаве АМГ6 при РКУП методом просвечивающей электронной микроскопии. Темнопольное изображение структуры сплава АМГ6 в матричном рефлексе показало разбиение материала на мелкие разориентированные фрагменты размером около 0,5 мкм с малоугловой границей разориентации (около $2-5^{\circ}$ ). На основе экспериментальных исследований выбран оптимальный режим РКУП алюминиевого сплава АМГ6, который позволяет получить заготовку с повышенными трибологическими и механическими характеристиками. Установлено, что наиболее интенсивное измельчение зеренной структуры в сплаве АМГ6 происходит при 12 проходах РКУП с углом пересечения каналов $120^{\circ}$. Показано, что с уменьшением размеров зерен микротвердость сплава АМГ6 после РКУП увеличивается в 4 раза, по сравнению с исходным состоянием. Результаты испытания образцов на абразивное изнашивание показали снижение потери массы после 12 проходов РКУП, что указывает на увеличение износостойкости сплава АМГ6 на $13-14 \%$, по сравнению с исходным состоянием.
\end{abstract}

Ключевые слова: равноканальное угловое прессование, алюминиевый сплав, дислокационная структура, микротвердость, износостойкость.

\section{References}

1 Elagin, V.I. (2008). Konstruktsionnye nanostrukturnye splavy na aliuminievoi osnove [Aluminum-based structural nanostructured alloys]. Tekhnolohiia lehkikh splavov — Light alloy technology, 2, 6-20 [in Russian].

2 Rakhadilov, B.K., Kylyshkanov, M., \& Zhaparova M.S. (2018). Evolution of the structure and properties of pure aluminum under severe plastic deformation. IOP Conference Series: Materials Science and Engineering, 447(1), 412-417.

3 Kalombo, R.B., Araujo, J.A., Ferreira, J.L.A., da Silva, C.R.M., Alencar, R., Capra, A.R., \& Kalombo, R.B. (2016). Assessment of the fatigue failure of an All Aluminium Alloy Cable (AAAC) for a $230 \mathrm{kV}$ transmission line in the Center-West of Brazil. Engineering Failure Analysis, 61, 77-87.

4 Valiev, R.Z., Islamgaliev, R.K., \& Alexandrov, I.V. (2000). Bulk nanostructured materials from severe plastic deformation. Progress in Materials Science, 45, 103-189.

5 Gleiter, H. (200). Nanostructured Materials: Basic concept and microstructure. Acta Mater, 48, 1-29.

6 Utyashev, F.Z., Raab, G.I., Shibakov, V.G., \& Ganiev, M.M. (2016). Teoriia i praktika deformatsionnykh metodov formirovaniia nanokristallicheskoi struktury $v$ metallakh i splavakh [Theory and practice of deformation methods for the formation of a nanocrystalline structure in metals and alloys]. Kazan: Kazan Univ. Publ. [in Russian].

7 Valiev, R.Z., Zhilyaev, A.P., \& Lengdon, T. Dzh. (2017). Obemnye nanostrukturnye materialy: fundamentalnye osnovy $i$ primeneniia [Bulk nanostructured materials: fundamental principles and applications]. Saint-Petersburg: Eko-Vektor [in Russian].

8 Cerri, E. (2010). An investigation of hardness and microstructure evolution of heat treatable aluminum alloys during and after equal-channel angular pressing. Materials Science Forum, 633-634, 333-340.

9 Segal, V.M. (2004). Razvitie obrabotki materialov intensivnoi sdvihovoi deformatsiei [Development of material processing by intensive shear deformation]. Metally - Metals, 1, 5-14 [in Russian].

10 Rakhadilov, B.K., Myakinin, A.A., Uazyrkhanova, G., \& Uazyrkhanova, Zh. (2016). Effect of intensive plastic deformation on microstructure and mechanical properties of aluminum alloys. IOP Conf. Series: Materials Science and Engineering, 142, 213217. 